Article

\title{
Investigation of the Relationship between the Perceived Public Transport Service Quality and Satisfaction: A PLS-SEM Technique
}

\author{
Karzan Ismael *(D) and Szabolcs Duleba (D)
}

Citation: Ismael, K.; Duleba, S. Investigation of the Relationship between the Perceived Public Transport Service Quality and Satisfaction: A PLS-SEM Technique. Sustainability 2021, 13, 13018. https:/ doi.org/10.3390/su132313018

Academic Editors: Ermanno C. Tortia and Elena Cristina Rada

Received: 21 September 2021 Accepted: 22 November 2021 Published: 24 November 2021

Publisher's Note: MDPI stays neutral with regard to jurisdictional claims in published maps and institutional affiliations.

Copyright: (c) 2021 by the authors. Licensee MDPI, Basel, Switzerland. This article is an open access article distributed under the terms and conditions of the Creative Commons Attribution (CC BY) license (https:/ / creativecommons.org/licenses/by/ $4.0 /)$.
Department of Transport Technology and Economics (KUKG), Faculty of Transportation Engineering and Vehicle Engineering (KJK), Budapest University of Technology and Economics (BME), 1111 Budapest, Hungary; duleba.szabolcs@kjk.bme.hu

* Correspondence: ismael.karzan@kjk.bme.hu

\begin{abstract}
Public transportation (PT) service quality is recognized as a cornerstone of infrastructure development in many countries. Understanding the satisfaction level of public transport users towards provided service quality is vital. However, there is still a lack of research to identify the specific relationship between the experience of service quality and private vehicle (PV) users' satisfaction. Therefore, this paper aimed to examine the different satisfaction attributes of PV users due to the COVID-19 pandemic and to make possible suggestions to policymakers on how to adapt to these changed attitudes. The paper highlights that some satisfaction issues became more significant, while the importance of others was mitigated due to the unusual circumstances. In this study, variance-based Partial Least Squares Structural Equation Modeling (PLS-SEM) was applied to test the proposed hypotheses. Further, Partial Least Squares Multi-Group Analysis (PLS-MGA) was conducted for investigating the perception of age and gender groups on the basis of gap analysis. An online panel and printed questionnaire survey were used to collect data in Budapest, Hungary in October and November 2020 during COVID-19 from the perception of 100 PV users. The findings show that perceived service quality and accessibility are statistically significant in the formation of PV users' satisfaction but safety and security were not significantly related to satisfaction. Additionally, results from PLS-MGA reveal that there was a significant difference among gender and age groups in achieving satisfaction associated with safety and security. The conclusions of this study are not only beneficial for the theory of this field but also contribute to practice for policymakers in terms of providing better service with specific identification of how to encourage more private vehicle users to use public transportation.
\end{abstract}

Keywords: perceived service quality; satisfaction; public transportation; private vehicle users; PLSSEM; multi-group analysis (MGA)

\section{Introduction}

Public transportation (PT) plays an important role in the promotion of sustainable mobility in urban areas [1]. Many statistics have proven that more and more people live in urban areas: in 2018 more than $50 \%$ of citizens lived in big cities and their suburbs, by 2050 this proportion is expected to increase to 68\% [2]. Despite of this, the number of private vehicle (PV) users has increased, resulting in traffic congestion, accidents and various environmental issues [2].

Previous studies mostly focused on PT users [3-6] and non-users [7] in evaluating public transportation service quality. However, an understanding of the perception of PV users is also required (at least perception of who have some knowledge about public transport services quality) [8-11].

Several developed countries, for example, Germany and Japan, strongly support urban PT as a main transport mode, because it plays a significant role in the movement of citizens 
in a more environmentally friendly manner compared to PV transport [12]. Another study concluded that encouraging PV users to move toward PT needs service planning, new policy, and infrastructure improvement [12]. For instance, during the COVID-19 pandemic in Budapest, Hungary public transport usage has greatly declined [13].

Researchers have used public transport satisfaction surveys to increase the number of PT customers [14]. Another study found that the perception of service quality is the main driver behind enhancing PT service quality [15]. In addition, literature has explored the relationship among service quality aspects [6].

However, the interrelationship among service quality attributes is a complicated topic [2]. Furthermore, it is limited, especially within Eastern Europe. Thus, more research is still needed to add the existing knowledge [13,16,17]. For instance, some scholars have recommended the examination of new interrelation theory among service quality attributes in different contexts [18].

In addition to these limitations, examining the relationship between public transport service quality and social demographic characteristics is crucial for PT service providers $[19,20]$. Both gender and age groups are the main factors that impact on the behaviour of passengers [21].

Consequently, a more accurate understanding of the service quality attributes has been suggested as a future research area to improve Budapest PT and attract more private vehicle users, and this has been the core objective of this research $[13,16]$.

So far, scholars have applied various different techniques such as, Importance Performance Analysis (IPA) [22], structural equation modeling (SEM) [4,23,24], partial least squaresstructural equation modeling (PLS-SEM) [25-27], discrete choice model (DCM) [5,8,28], and multi-criteria decision making (MCDM) groups [29], Bayesian Network (BN) [6,18,30]. SEM has been successfully applied to examine the relationships between variables [31]. This paper applied PLS-SEM the selection of which is based on different criteria, including nature of the research, type of data, sample size and gap analysis.

There is a general agreement for increasing the number of PT users and striving to reduce the number of PV users. Finding the main attribute that affects people satisfaction and contributes to attracting PV users to PT users is an important consideration for researchers and authorities, since providing a high quality of service is essential to encourage PV users to increase their utilization of public transport [32]. However, it is not always guaranteed to contribute to satisfying people [33].

Concerning the shortages discussed in the literature, this study aims to fill the gaps using empirical data from a PV user's perspective to contribute in the following ways:

- Applying an effective PLS-SEM approach to test, analyze, and develop three new service constructs for use during COVID-19 which take account of practical implications [13].

- Discover the interrelation between perceived service quality and satisfaction regarding public transport service performance, from the private vehicle usage point of view, which has been recommended recently [16,17].

- Investigate the differences in perception between men and women, as well as among different age groups, as suggested in the literature [16,30,34,35].

Finally, this study can help transport service providers to identify and improve the specific issues among different service attributes, especially during the COVID-19 pandemic. The remainder of this article is organized as follows: Section 2 provides the theoretical background and hypotheses development. The analysis methods and survey design are presented in Section 3, followed by the results in Section 4. The discussions and implications are presented in Section 5. In the last section, concluding remarks are drawn and some recommendations are made for future study.

\section{Literature Review and Research Hypotheses}

In this section the details of selected methods and three main aspects (perceived service quality, accessibility, safety and security) are described based on theoretical background. 
In light of previous studies to examine PT service quality, structural equation model (SEM) has been applied for analyzing the causal relationships between service quality and satisfaction [23]. Naturally, the SEM was divided into covariance-based applications (CB-SEM), using AMOS and those using partial least squares structural equation modeling (PLS-SEM) using SmartPLS 3.0 [31]. Much consideration was given to the use of PLSSEM which is widely used in different social science studies, for example in business, market studies, education, and tourism [31,36], and in construction management [37]. In addition, PLS-SEM has been applied in transportation planning research and analysis of the heterogeneity $[25,38]$. A review article concluded that PLS-SEM has a significant role in operation research [39]. This method is capable of providing a higher level of statistical robustness even with a small sample size $[31,40,41]$. Additionally, PLS-SEM does not require normally distributed data [42]. A recent comparison study between CB-SEM and PLS-SEM found that both techniques are applicable in social science, however, CB- SEM requires normal data in a distribution [43].

PLS-SEM is a non-parametric approach, it works with ordinal and scale data. Moreover, PLS-SEM is used as an alternative technique to CB-SEM, because the PLS-SEM technique can deal with both reflective and formative models. Conversely, CB-SEM can only deal with reflective models [26,44]. Regarding the analyzing of heterogeneity and using segmentation, methods such as structural equation model-multi-group analysis (SEM-MGA) have been used between two groups [27]. Structural equation model-multiple indicator multiple cause (SEM-MIMIC) ordinal Probit was proposed to investigate the heterogeneity of perception of passengers [45]. A study revealed that the traditional SEM methods can only show the heterogeneity partially and unobserved heterogeneity (e.g., by age or gender) cannot be accurately examined [46]. On the other hand, other research stated that applying the finite mixture partial least squares (FIMIX-PLS) methodology can be suitable for transport operators, as this technique considers different segmentations and contributes to a more specific intervention [38]. Thus, the current study performed a rigorous PLS-SEM method and PLS-MGA for private vehicle users who have knowledge about PT service quality.

Service quality is one of the main predictors of satisfaction [47]. Recently, customer satisfaction linked to perceived PT service quality, accessibility and safety has been widely studied which is important in understanding the cause-and-effect relationship towards sustainable transport $[45,48]$. Traffic externality issues (i.e., noise, environmental pollution) may be exacerbated by excessive usage of PVs and less use of PT [49-51]. Therefore, the main aim of transport operators and service providers is to increase the accessibility and safety for PT passengers [52].

In order to achieve the aim of service providers, further study is required, because some concepts are still hidden and it may be inaccurate to generalize the results $[2,53]$. Further, the concept of service quality and satisfaction are analyzed differently [25,47]. There is a general agreement between scholars that examination of PT service quality by considering the perspective of PT passengers is an appropriate method for transport service providers [28,54-56]. Although, several studies in practice identified and suggested differences between satisfaction and perceived service quality, both of these terms are used interchangeably because they relate to the perception of the individual. For example, the judgment for service quality is quite specific, but the judgment for satisfaction is more general. Previous research argued that the perceived service quality influences the examination of satisfaction level [57]. Further studies claimed that where an assessment suggests improvement of perceived service quality this also results in improved satisfaction [58,59]. Based on the above discussion, perceived service quality was hypothesized to influence PV user satisfaction as follows:

Hypotheses 1 (H1). Perceived service quality has a positive effect on the satisfaction level of private vehicle users. 
Many studies agreed that working together is crucial for the development of sustainable transportation that is more accessible to those people with physical or other impairment problems [1]. Some scholars mentioned that the objective of transport operators is to provide a service which facilitates easy movement for disabled people and provides an accessible connection between land use, transportation movement and potential interactions, [60-62]. Another author showed that accessibility has a crucial influence on individual choice [63]. In addition, another study found that the accessibility attribute can determine the impact of the transport network [64]. However, there are few practical studies that have investigated this topic [52]. As a result, the following hypothesis of relationships between perceived accessibility and PV passenger satisfaction is proposed:

Hypotheses 2 (H2). Perceived accessibility has a positive impact on the satisfaction of private vehicle users.

Looking at the terms of safety and security, perceptions of both safety and security are measured as critical issues that strongly impact public transport users [27]. Many studies concluded that the perception of safety is a major factor contributing to PT customer satisfaction $[65,66]$. Furthermore, another study claimed that safety can be achieved by providing reliable service, including professional staff, and cleanliness and comfort inside the vehicle, however, where public transport has lower quality of service this probably increases risk and negatively influences feelings of personal safety [52]. In the papers of the European Commission, the security issue is related to three major problems: safety from both crime and accidents, and the perceptions of citizens in terms of security [27,67]. Some researchers have used safety and security with all quality indicators [66,68]. However, another study utilized the aspects separately to assess the service quality of public transportation [69]. According to a report on crime concern for the United Kingdom department of transport approximately $10 \%$ of citizens would reconsider using of public transport if their safety fears could be addressed [70]. Consequently, increasing PT safety (for example by achieving a reduced number of crimes and likelihood of accidents) is crucial to attracting more passengers to use public transport [71]. Thus, based on the facts in the literature we propose the following hypothesis to address this gap, especially during the COVID-19 pandemic.

Hypotheses 3 (H3). Perceived safety and security are positively related to private vehicle users' satisfaction.

Figure 1 shows the theoretical framework for the research model which is proposed by the authors. The authors expect that perceived service quality, accessibility, safety and security will contribute to satisfaction of PV users. Hence, in the current study, three hypotheses are formulated for these relationships.

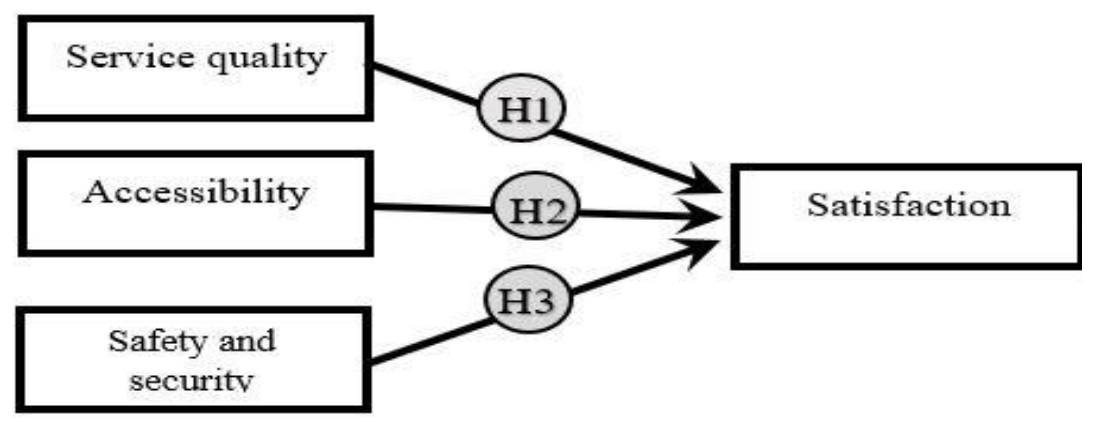

Figure 1. Conceptual model.

\section{Materials and Methods}

Due to the complexity of the proposed model, partial least squares-structural equation modeling (PLS-SEM) was employed for data analysis in this study. Several benefits and motivations are mentioned in the literature, suggesting that PLS-SEM well suited 
for exploration in this research. As a result, SPSS 24.0 and SmartPLS 3.0 were used to analyze the data. A systematic procedure for data analysis included demographic information, measurement model evaluation, assessment of the structural model and, finally, the heterogeneity analysis between different groups.

\subsection{Analysis Methods}

The PLS-SEM approach contains principal component analysis with ordinary least squares regression, to examine the association between manifest (observed) variables and latent (unobserved variables). The PLS path model is described by two models as follows [72,73]:

1. The measurement model (also referred to as the outer model): This model shows the relationship between observed variables with their constructs. The two types of measurement model (reflective or formative) are presented in Equations (1) and (2):

$$
\mathrm{X}_{\mathrm{h}}=\pi_{\mathrm{h} 0}+\pi_{\mathrm{h}} \xi+\varepsilon_{\mathrm{h}}
$$

Equation (1) presents the reflective measurement, in which each manifest variable (MV) is related to the latent variable (LV), which is represented by simple regression, where $X_{h}$ is the manifest variable, $\pi_{h}$ is the loading corresponding to the manifest variable; $\xi$ is the latent variable to which the manifest variables $\left(X_{h}\right)$ are related, and $\varepsilon_{\mathrm{h}}$ is the error term.

$$
\xi=\sum \mathrm{W}_{\mathrm{h}} \mathrm{X}_{\mathrm{h}}+\delta
$$

Equation (2) shows a formative measurement, which assumes that the latent variable is generated by manifest variables. Thus, the latent variable is a linear function of its manifest variables plus a residual term, where $\mathrm{W}_{\mathrm{h}}$ is the weight corresponding to (MV) and $\delta$ is the residual term.

2. The structural model (also referred to as the inner model): This model illustrates the interrelationships among the constructs, which can be dependent (endogenous) or independent (exogenous) variables, by determining the path coefficients. Thus, the PLS-SEM model is illustrated in Equation (3):

$$
\xi_{\mathrm{j}}=\beta_{\mathrm{j} 0}+\sum \beta_{\mathrm{ji}} £_{\mathrm{i}}+\mathrm{v}_{\mathrm{j}}
$$

where $\xi_{j}$ is the jth unobserved variable with ' $i$ ' number of unobserved variables; $\beta$ is the regression coefficient term for unobserved variables; $v_{j}$ is the error term related to $\xi_{j}[6]$.

As we have shown previously, this study performed PLS-SEM to test the proposed model as presented in Figure 1. To analyze the model, SmartPLS 3.0 was utilized, as an appropriate software for analysis of both formative and reflective models which was developed by Christian M. Ringle, Sven Wende, and Jan-Michael Becker [74]. Additionally, the nature of the study is explanatory, thus, PLS-SEM has been fitted for the analysis [75]. For PLS-SEM, as presented in a review article, the minimum sample size is determined by the 10 times rule as proposed by Barclay in 1995 [76]. On the other hand, it has also been recommended to use $G^{*}$ Power to determine the sample size [76]. The calculation process to identify the sufficient sample size was performed at a $5 \%$ level of significance and $80 \%$ power with 0.15 effect size and a maximum of 3 predictors.

Findings from the power analysis show that a sample size of 77 is required for the proposed model. This confirms that the sample size used for analysis in this research is sufficient. Moreover, to cope with the higher heterogeneity, in the last step, multi-group analysis (MGA) was employed to examine the significant difference between two gender groups (male vs. female) and two different age groups (18-44 vs. $\geq 45$ ). The segmentation of samples using MGA makes it possible to simultaneously fit the model to data from multiple groups which is in line with Sarstedt's et al. recommendation [77]. It is worth mentioning that MGA is a useful method to examine the moderation among various relationships and to find the heterogeneity across groups [36]. 


\subsection{Sample Design and Survey Location}

A comprehensive screening procedure was conducted, as a part of the preparation for data analysis. The data was tested for any potential statistical error, for instance, normality, outliers, missing values common method variance, correlation and multicollinearity test. However, there were very few missing values that were excluded from data analysis. As the regression analysis does not work with missing values, we have to have a complete case analysis. Since we are dealing with 5-Point-Likert scale data, we have not conducted outlier analysis, as it might not make much sense. Moreover, in this study, the analysis data and discuss research results begin with a short explanation of the research case study and socio-demographic characteristics. The survey contains two parts, first a brief description of socio-demographic attributes of participants including their age, gender, income, education level and mobility and second the perception of PV users regarding PT service provided in the area. Additionally, a basic statistical analysis was conducted.

The data on perception of PV users gathered in this study was limited to the capital city of Budapest, Hungary. It is one of the developed and congested cities located in Eastern Europe. Furthermore, according to the Hungarian central statistical office, Budapest city covered an area of $525.2 \mathrm{~km}^{2}$ with a population of approximately 1.7 million in 2020 [78]. It is divided by the River Danube into the Buda and Pest parts areas. Budapest city contains 23 districts see Figure 2, and the data was collected in all districts. The public transportation service is provided by transport operator (BKK) for day and nighttime including metro, tram, bus and train [79]. Budapest is a hub for business and education in Hungary and, in addition to that, it is an attractive tourist destination within Europe with unique cultural and socio-economic significance. Increasing demand for traveling was a key driver for conducting this study in Budapest city. However, more accurately understanding the service quality attributes recommended to improve Budapest PT and attract more PV users has been the core objective of this research [16].

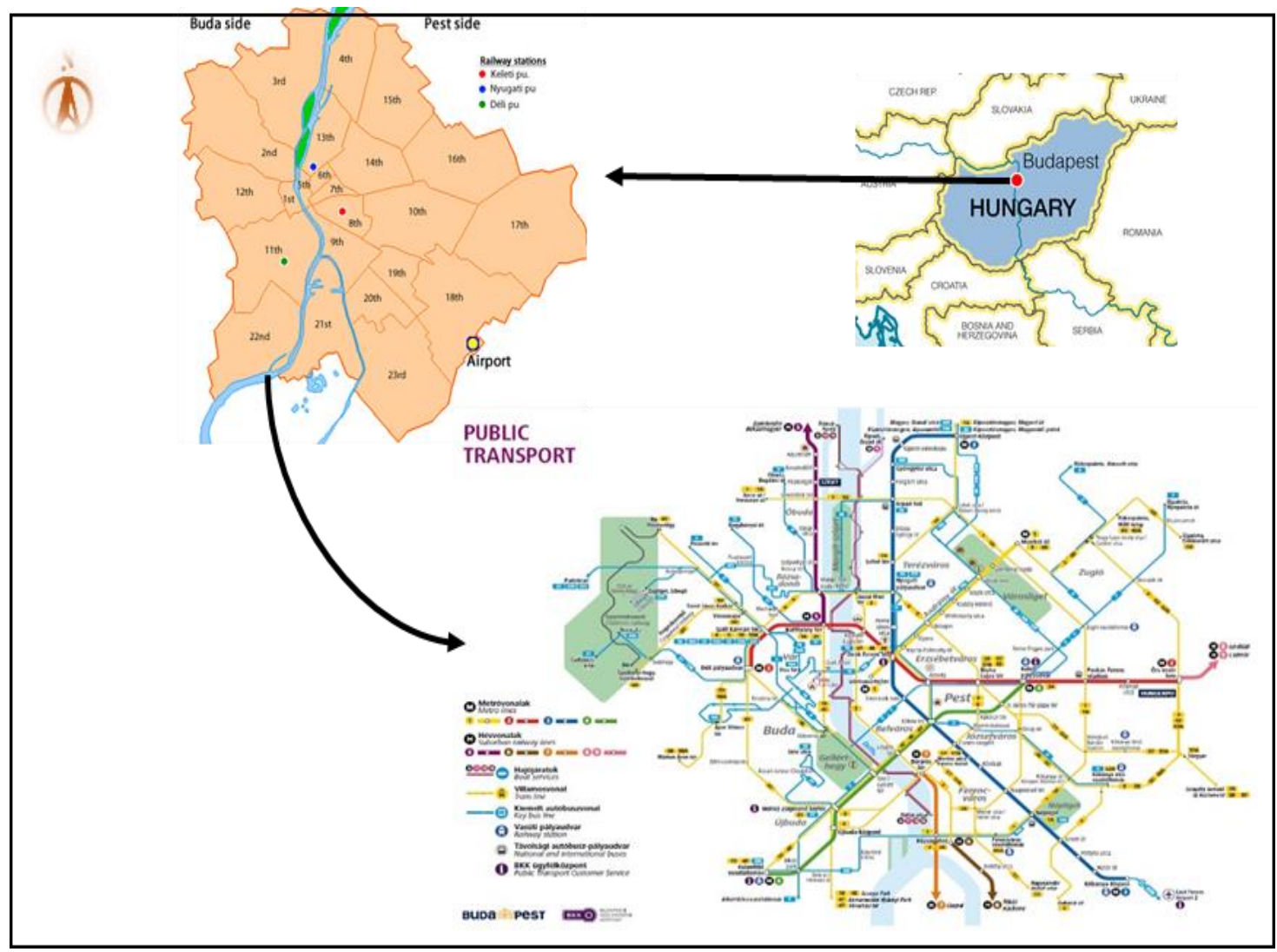

Figure 2. Transport map of Budapest and districts. 
The collected data used for analysis in this study were obtained from an online panel and printed questionnaire survey carried out in Budapest, Hungary in October and November 2020 during the COVID-19 pandemic in both English and local (Hungarian) languages. Tables 1 and 2 show details of the survey and characteristics of the data. In this study, the survey targeted a total of 100 private vehicle users without missing values. The PV users were asked to score their perception of the satisfaction level associated with the PT service provided. For this reason, for each service attribute, a 5-point Likert scale ranging from 1 to 5 was utilized (where 1 meant "very unsatisfied" and 5 meant "very satisfied"). The survey included male (52\%), female (48\%); the majority of participants were aged $25-44(49 \%)$, followed by $45-64(27 \%)$, and $18-24(18 \%)$, while only $6 \%$ were over 65 years old; and $43 \%$ were employed.

Table 1. Survey respondent characteristics.

\begin{tabular}{|c|c|c|c|}
\hline Character & $\%$ & Character & $\%$ \\
\hline Gender & & Current occupation & \\
\hline Male & 52 & Self-employed & 11 \\
\hline Female & 48 & Employed & 43 \\
\hline Age & & Unemployed & 5 \\
\hline $18-24$ & 18 & Student & 32 \\
\hline $25-44$ & 49 & Retired/Pensioner & 3 \\
\hline $45-64$ & 27 & Household tasks & 6 \\
\hline $65+$ & 6 & Living in the area & \\
\hline Income & & Less than a year & 31 \\
\hline Less than 56,300 HUF (1596 Euro) & 66 & A few years & 49 \\
\hline Between 563,000 (1596 Euro)—1,408,000 HUF (3991 Euro) & 23 & All my life & 20 \\
\hline Above $1,408,000 \mathrm{HUF}$ & 7 & PT use in a normal week & \\
\hline Education level & & Habitual user & 64 \\
\hline With university degree & 81 & Ocational user & 36 \\
\hline Without university degree & 19 & & \\
\hline
\end{tabular}

Furthermore, Table 2 illustrates that the majority of participants (66\%) earned a low income less than 563,000 HUF, which is equivalent to around 1600 Euro, $23 \%$ of participants had an income ranges of 1600-4000 Euro, and only small number of participants (7\%) earned a high income. The majority of private vehicle users were educated with a university degree $(81 \%)$. Regarding the current occupation, the proportion of participants who were employed, students, self-employed, working at home, unemployed or retired were $43 \%$, $32 \%, 11 \%, 6 \%, 5 \%$, and $3 \%$ ), respectively.

It is worth mentioning that the questions were asked of those people who were familiar with the provided service or at least had some knowledge about the service and were hence in a position to make a valid judgment of public transportation service quality. Thus, many of the participants in the survey (49\%) had been living in the area for few years $31 \%$ of them had lived in the area for less than one year, and $20 \%$ had lived in the area for their whole life. Table 2 illustrates three main constructs including 14 PT service attributes and 1 item (overall satisfaction). All indicators were obtained from the recent study [8]. Private vehicle users scored a satisfaction level regarding the PT service of 3.65 which was above the average of the quality-of-service attributes scores (3.39). Service hours and individual space showed the highest average scores (3.92 and 3.92), followed by frequency (3.84) and proximity (3.80). Interestingly, temperature and cleanliness had the lowest average scores (2.48 and 2.68, respectively). For more detail, we have presented several figures to show the distribution of scores for each attribute (see Figure A1 in the Appendix A). These figures show that the data is not normally distributed. 
Table 2. Basic statistics about service quality, accessibility, safety and security with satisfaction.

\begin{tabular}{|c|c|c|c|c|c|}
\hline Construct & Indicators & Description & Scale * & Sign & Mean \\
\hline Service quality & Service hours & Service hours & $1-5$ & SQ1 & 3.92 \\
\hline \multirow[t]{6}{*}{$(\mathrm{SQ})$} & Proximity & $\begin{array}{l}\text { The proximity of stops to starting point or } \\
\text { destination of the trip }\end{array}$ & $1-5$ & SQ2 & 3.80 \\
\hline & Frequency & Number of daily services & $1-5$ & SQ3 & 3.84 \\
\hline & Punctuality & Punctuality & $1-5$ & SQ4 & 3.69 \\
\hline & Speed & Speed & $1-5$ & SQ5 & 3.51 \\
\hline & Cost & Cost of ticket & $1-5$ & SQ6 & 3.43 \\
\hline & Information & Provided information & $1-5$ & SQ7 & 3.50 \\
\hline \multirow[t]{3}{*}{$\begin{array}{l}\text { Accessibility } \\
\text { (AC) }\end{array}$} & Easy from stations & $\begin{array}{c}\text { Ease of entrance and exit from the vehicle } \\
\text { and/or stations. }\end{array}$ & $1-5$ & $\mathrm{AC} 1$ & 3.34 \\
\hline & Intermodality & $\begin{array}{c}\text { Ease of transfers/good connections with other } \\
\text { modes of transport }\end{array}$ & $1-5$ & AC2 & 3.55 \\
\hline & Individual space & Individual space is available inside the vehicle. & $1-5$ & AC3 & 3.92 \\
\hline \multirow{4}{*}{$\begin{array}{l}\text { Safety and security } \\
\text { (SS) }\end{array}$} & Temperature & The temperature inside the vehicle. & $1-5$ & SS1 & 2.48 \\
\hline & Cleanliness & Cleanliness of the vehicle and stations. & $1-5$ & SS2 & 2.68 \\
\hline & Accident & Safety on board (regarding accidents). & $1-5$ & SS3 & 3.59 \\
\hline & Robbery & Safety regarding robbery and violence. & $1-5$ & SS4 & 3.18 \\
\hline \multirow[t]{3}{*}{$\begin{array}{l}\text { Satisfaction } \\
\qquad(\mathrm{SA})\end{array}$} & $\begin{array}{c}\text { General } \\
\text { satisfaction }\end{array}$ & $\begin{array}{l}\text { In general, I am satisfied with the public } \\
\text { transport service provided in my area. }\end{array}$ & $1-5$ & SA1 & 3.77 \\
\hline & Expectation & $\begin{array}{l}\text { The public transport service in the area meets } \\
\text { my expectations. }\end{array}$ & $1-5$ & SA2 & 3.57 \\
\hline & Need & $\begin{array}{l}\text { With the existing modes of transport in the } \\
\text { area, I consider that the commuting needs of } \\
\text { inhabitants are well covered. }\end{array}$ & $1-5$ & SA3 & 3.62 \\
\hline
\end{tabular}

* The indicators are measured on a 1-5 Likert scale (where 1 means "very unsatisfied", 2 means "unsatisfied", 3 means "neutral", 4 means "satisfied" and 5 means "very satisfied").

\section{Results}

In this section, we present the initial tests and results of identifying the main attributes that impact satisfaction and movement towards using public transportation from the private vehicle users' point of view.

\subsection{Preliminary Tests}

Correlation analysis among independent variables was adopted to verify the degree to which two variables are related. Based on the results in Table 3 (variance-covariance matrix), it can be seen that service hours (SQ1) have a higher correlation coefficient with proximity and frequency (SQ2 and SQ3, respectively), followed by proximity (SQ2) and frequency (SQ3). In addition, a higher correlation can also be seen between temperature (SS1) and cleanliness (SS2). This suggests that there may be some degree of collinearity among independent variables. However, the findings of the multicollinearity test in Table 4 , show that there is no issue regarding multicollinearity of data because the variation inflation factors (VIFs) for almost all variables are less than or equal to 5 which is the recommended cut-off value [80]. In addition to that, the VIF value in PLS-SEM was also assessed for further investigation. Results between 1.81 and 1.95 were obtained at factor level, which is less than the suggested threshold value of 3.3, indicating there is no method bias with the data [81].

\subsection{Common-Method Variance Bias Test}

From the methodological issues, the common method bias refers to measurement error. For instance, having a common measurement scale (e.g., 5-point Likert scale) for all survey questions may lead to common method bias. In this study, to identify the likely presence of common method variance bias among variables, we utilized Harman's single factor test, which is widely used. This involved entering all items of the measurement scale into a principal component analysis. The total variance explained by the single factor is 
only $47.5 \%$ which is below the recommended cut-off of $50 \%$. Based on this result, in this research, the common method bias is not a problem, and the collected data is suitable for further analysis.

Table 3. Correlation matrix.

\begin{tabular}{lllllllllllllll}
\hline & SQ1 & SQ2 & SQ3 & SQ4 & SQ5 & SQ6 & AC1 & AC2 & AC3 & SS1 & SS2 & SS3 & SS4 & SQ7 \\
\hline SQ1 & 1.00 & & & & & & & & & & & & & \\
SQ2 & $\mathbf{0 . 8 1}$ & 1.00 & & & & & & & & & & & & \\
SQ3 & $\mathbf{0 . 8 0}$ & $\mathbf{0 . 7 8}$ & 1.00 & & & & & & & & & & & \\
SQ4 & 0.68 & 0.67 & 0.66 & 1.00 & & & & & & & & & & \\
SQ5 & 0.58 & 0.70 & 0.65 & 0.57 & 1.00 & & & & & & & & & \\
SQ6 & 0.36 & 0.33 & 0.33 & 0.30 & 0.27 & 1.00 & & & & & & & & \\
AC1 & 0.31 & 0.30 & 0.36 & 0.40 & 0.29 & 0.52 & 1.00 & & & & & & & \\
AC2 & 0.44 & 0.59 & 0.47 & 0.51 & 0.47 & 0.46 & 0.64 & 1.00 & & & & & & \\
AC3 & 0.16 & 0.24 & 0.20 & 0.29 & 0.31 & 0.42 & 0.54 & 0.47 & 1.00 & & & & & \\
SS1 & 0.20 & 0.19 & 0.21 & 0.21 & 0.27 & 0.42 & 0.45 & 0.34 & 0.60 & 1.00 & & & & \\
SS2 & 0.18 & 0.14 & 0.13 & 0.22 & 0.18 & 0.34 & 0.45 & 0.31 & 0.54 & $\mathbf{0 . 7 2}$ & 1.00 & & & \\
SS3 & 0.49 & 0.45 & 0.43 & 0.50 & 0.45 & 0.37 & 0.43 & 0.49 & 0.44 & 0.39 & 0.44 & 1.00 & & \\
SS4 & 0.51 & 0.50 & 0.40 & 0.48 & 0.39 & 0.40 & 0.37 & 0.35 & 0.37 & 0.36 & 0.40 & 0.65 & 1.00 & \\
SQ7 & 0.50 & 0.50 & 0.43 & 0.53 & 0.42 & 0.41 & 0.37 & 0.44 & 0.41 & 0.36 & 0.43 & 0.62 & 0.58 & 1.00 \\
\hline
\end{tabular}

Table 4. Multicollinearity results.

\begin{tabular}{lllllllllllllll}
\hline & SQ1 & SQ2 & SQ3 & SQ4 & SQ5 & SQ6 & SQ7 & AC1 & AC2 & AC3 & SS1 & SS2 & SS3 & SS4 \\
\hline VIF & 4.43 & 5.23 & 3.72 & 2.45 & 2.26 & 1.65 & 2.10 & 2.42 & 2.77 & 2.07 & 2.54 & 2.50 & 2.43 & 2.22 \\
\hline
\end{tabular}

\subsection{Assessment of Measurement Model}

The reliability and validity were tested by using Composite Reliability (CR) to evaluate internal consistency and Average Variance Extracted (AVE) to assess convergent validity $[82,83]$. Table 5 shows that the assessment applied in this model is reliable [82-84]. The AVE of all latent variables was $>0.5$, indicating high convergent validity among constructs.

Table 5. Measurement model results.

\begin{tabular}{|c|c|c|c|c|c|}
\hline Construct & Manifest Variable & Factor Loading a & Cronba Ch's $\alpha^{b}$ & $\operatorname{AVE}^{\mathrm{c}}$ & $\mathrm{CR}^{\mathrm{d}}$ \\
\hline \multirow[t]{3}{*}{ Accessibility } & $\mathrm{AC} 1$ & 0.876 & 0.786 & 0.692 & 0.870 \\
\hline & $\mathrm{AC} 2$ & 0.899 & & & \\
\hline & $\mathrm{AC} 3$ & 0.708 & & & \\
\hline \multirow{4}{*}{$\begin{array}{l}\text { Safety and } \\
\text { security }\end{array}$} & SS1 & 0.650 & 0.796 & 0.594 & 0.852 \\
\hline & SS2 & 0.679 & & & \\
\hline & SS3 & 0.887 & & & \\
\hline & SS4 & 0.841 & & & \\
\hline \multirow[t]{3}{*}{ Satisfaction } & SA1 & 0.922 & 0.924 & 0.868 & 0.952 \\
\hline & SA2 & 0.944 & & & \\
\hline & SA3 & 0.928 & & & \\
\hline \multirow{7}{*}{$\begin{array}{l}\text { Service } \\
\text { quality }\end{array}$} & SQ1 & 0.877 & 0.890 & 0.616 & 0.917 \\
\hline & SQ2 & 0.886 & & & \\
\hline & SQ3 & 0.862 & & & \\
\hline & SQ4 & 0.819 & & & \\
\hline & SQ5 & 0.762 & & & \\
\hline & SQ6 & 0.547 & & & \\
\hline & SQ7 & 0.681 & & & \\
\hline
\end{tabular}

a. All item loadings $>0.5$ indicates indicator reliability; ${ }^{b}$. All Cronbach's alpha $>0.7$ indicates indicator reliability; c. All average Variance Extracted (AVE) $>0.5$ indicates convergent reliability; ${ }^{\mathrm{d}}$. All Composite Reliability $(\mathrm{CR})>$ 0.7 indicates internal consistency. 
The first step, Fornell-Larcker criterion was performed to find the discriminant validity, the results are shown in Table 6. Recently, the Heterogtrait-Monotrait (HTMT) ratio correlation has been introduced for assessing discriminant validity [85], the outcomes presented in Table 7 that are below the threshold of 0.85 .

Table 6. Discrimination validity (Fornell-Larcker criterion).

\begin{tabular}{cllll}
\hline & ACC & SS & SA & SQ \\
\hline Accessibility & $\mathbf{0 . 8 3 2}$ & & & \\
Safety and security & 0.609 & $\mathbf{0 . 7 7 1}$ & & \\
Satisfaction & 0.540 & 0.427 & $\mathbf{0 . 9 3 2}$ & \\
Service quality & 0.604 & 0.639 & 0.636 & $\mathbf{0 . 7 8 5}$
\end{tabular}

Values in the bold are the square root of AVE. Bold values are loadings for items, which are above the recommended value of 0.5 .

Table 7. Discrimination validity HTMT.

\begin{tabular}{ccccc}
\hline & ACC & SS & SA & SQ \\
\hline Accessibility & & & & \\
Safety and security & 0.827 & & & \\
Satisfaction & 0.593 & 0.429 & & \\
Service quality & 0.698 & 0.697 & 0.699 & \\
\hline
\end{tabular}

In summary, according to the results presented here, discriminant validity has been established. Thus, the measurement model is reliable and valid.

\subsection{Structural Model}

Having established reliability and validity in the assessment of the measurement model, the structural model was applied using the bootstrapping technique with 5000 subsamples. The objective was to examine the relationship between dependent (endogenous) and independent (exogenous) variables, and also to test the significance of path coefficients ( $\beta$-values). The assessment of PLS-SEM includes path coefficients to evaluate the significance of structural model relationships, $\mathrm{R}^{2}$ value is estimated the model is an accuracy, and $\mathrm{f}^{2}$ to assess the significant impact of the independent variable on a dependent variable [83]. The findings of the path model are displayed in Figure 3 and Table 8.

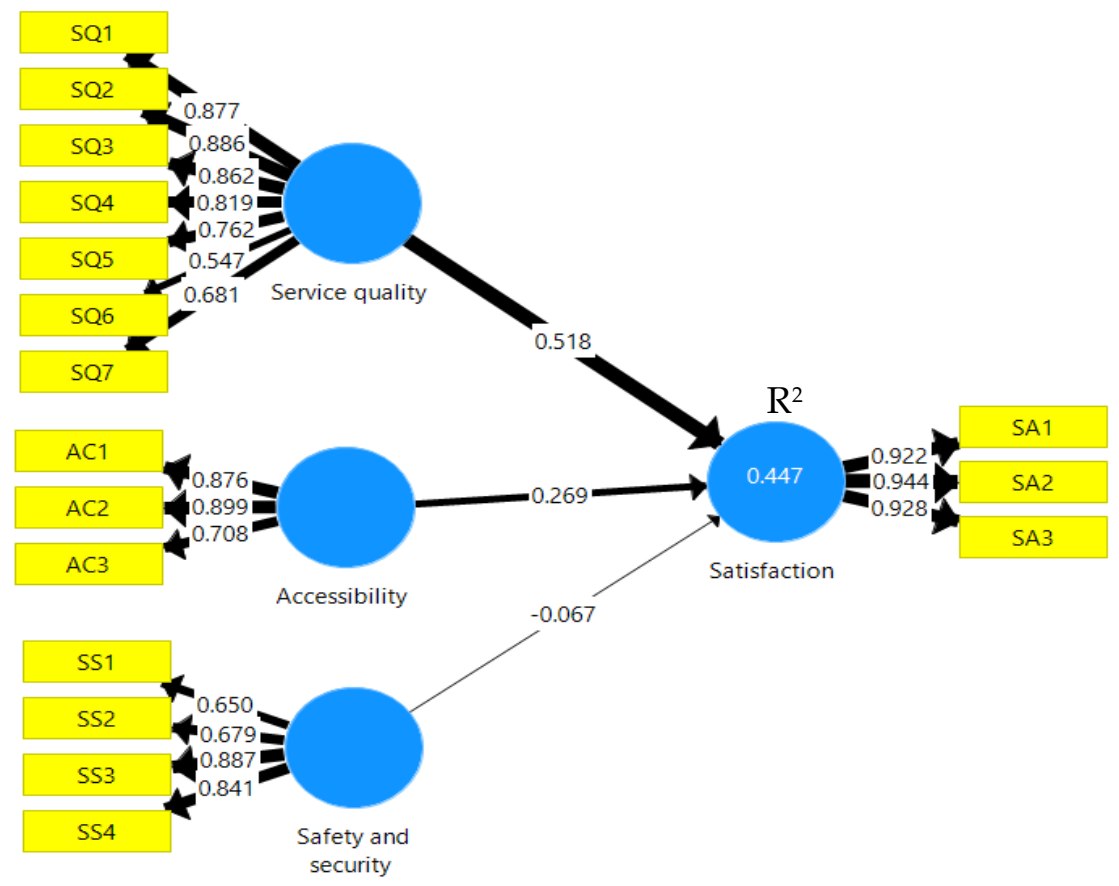

Figure 3. Findings of the structural model. 
Table 8. Structural estimates (Hypothesis assessment).

\begin{tabular}{ccccccc}
\hline Hypothesis & Relationship & B-Value & t-Value & Decision & $p$-Value & $\mathbf{f}^{2}$ \\
\hline H1 & $\begin{array}{c}\text { Service } \\
\text { quality->satisfaction } \\
\text { Accessibility-> } \\
\text { H2 }\end{array}$ & 0.518 & 4.079 & Supported & 0.000 & 0.252 \\
H3 & $\begin{array}{c}\text { Safety and } \\
\text { security->Satisfaction }\end{array}$ & -0.269 & 2.489 & $\begin{array}{c}\text { Supported } \\
\text { Not }\end{array}$ & 0.013 & 0.072 \\
\hline
\end{tabular}

The value of $R^{2}$ in Figure 3 indicates that the PV customers' satisfaction has $44.7 \%$ of explanatory power with $\mathrm{R}^{2}=0.447$ which is considered as a moderator [82]. Moreover, as the results in Table 7 show, that the service quality $(\beta=0.518 ; \mathrm{t}$-value $=4.079 ; p$-value $=0.000)$ is significant predictor of PV users' satisfaction at level $p<0.05$ and positive, providing to support H1. Similarly, $\mathrm{H} 2$ has been supported by the relationship between accessibility and satisfaction $(\beta=0.269$; $t$-value $=2.489 ; p$-value $=0.013)$ as accessibility is also a significant predictor of PV users' satisfaction to PT service. However, H3, concerning the relationship between safety and security with satisfaction $(\beta=-0.067$; $\mathrm{t}$-value $=0.509 ; p$-value $=0.611$, is not supported, with a non-significant predictor of PV user satisfaction to PT service (value of 0.611 being > 0.05). Hence, $\mathrm{H} 1$ and $\mathrm{H} 2$ are accepted while, $\mathrm{H} 3$ is rejected. For a better understanding of the proposed model, effect size values $\left(\mathrm{f}^{2}\right)$ were measured. An $\mathrm{f}^{2}$ value above 0.15 is considered as a good enough effect (moderate effect), less than 0.02 is considered a small effect, and anything above 0.35 is a large effect [86]. The findings for $\mathrm{f}^{2}$ also can be seen in Table 8 , and it is demonstrated that the path of service quality has the largest effect size on PV users' satisfaction with $\left(f^{2}=0.252\right)$ followed by accessibility $\left(f^{2}=0.072\right)$ as a small effect on the dependent variable, but safety and security have a very small effect on the PV satisfaction to PT service quality $\left(\mathrm{f}^{2}=0.004\right)$.

\subsection{Predictive Evaluation}

Predictive accuracy and relevance tests of the model are the main steps in assessing application of PLS-SEM. As we have shown, the predictive accuracy according to the coefficient of determination ( $R^{2}$ value), was at a moderate level ( 0.447 being $>0.33$ ) [87]. On the other hand, in SmartPLS 3.0 using the blindfolding procedure, the predictive relevance was tested to calculate $\mathrm{Q}^{2}$. Based on the recommendation in the literature, $\mathrm{Q}^{2}>0$ indicates predictive relevance in the model among endogenous attributes [88]. The findings present that the total $Q^{2}$ is positive (0.365) and all other $Q^{2}$ values are generated as positive from construct cross-validated redundancy. Thus, it is indicated that the proposed model in this study has sufficient predictive relevance.

\subsection{Goodness of Fit (GoF)}

PLS-SEM does not create general Goodness of Fit $(\mathrm{GoF})$, however, $\mathrm{R}^{2}$ value as an essential method can be considered to examine the explanatory power of the model [72]. Previous research used the GoF index for PLS-SEM to evaluate the model fit [89]. The $\mathrm{GoF}$ is assessed by utilizing the AVE value obtained from the measurement model and the average $R^{2}$ value. This can be calculated using the following equation, GoF $=\sqrt{ }\left(A V E \times R^{2}\right)$. The following cut-off values are reported in the literature for measuring the results of GoF analysis: GoFsmall $=0.1 ;$ GoFmedium $=0.25$; GoFlarge $=0.36$ [89]. On the basis of this guideline, we have calculated the GoF index of the model presented in this research, which is shown in Table 9. According to the result presented, the conceptual model utilized in this study generates a GoF index value of 0.556 , pointing toward a very good (GoFlarge) model fit. Thus, it can be concluded that from the complete analysis, both measurement models and structural models are validated. Furthermore, the results show that the conceptual model of this research has a significant predictive, as well as explanatory power. 
Table 9. Calculation of Goodness of Fit (GoF) index.

\begin{tabular}{cll}
\hline Constructs & AVE & $\mathbf{R}^{\mathbf{2}}$ \\
\hline Accessibility & 0.692 & \\
Safety and security & 0.594 & \\
Service quality & 0.616 & 0.447 \\
Satisfaction & 0.868 & 0.447 \\
Average scores & 0.693 & \\
AVE $\mathrm{R}^{2}$ & 0.309 & \\
$\mathrm{GoF}=\sqrt{ }\left(\mathrm{AVE} \times \mathrm{R}^{2}\right)$ & 0.556 & \\
\hline
\end{tabular}

\subsection{Partial Least Square Multi-Group Analysis (PLS-MGA)}

Before running the test for multi-group analysis, testing the measurement invariance of composite models (MICOM) is required with three steps (to make it clear for readers we created Figure 4) [36,72]. Moreover, having carried out the data preparation with 52 samples for males and 48 samples for females, data groups were generated for both groups to make a comparison. Correspondingly, for the two different age groups 67 respondents were between 18-44 years old and 33 respondents were above 45 years old.

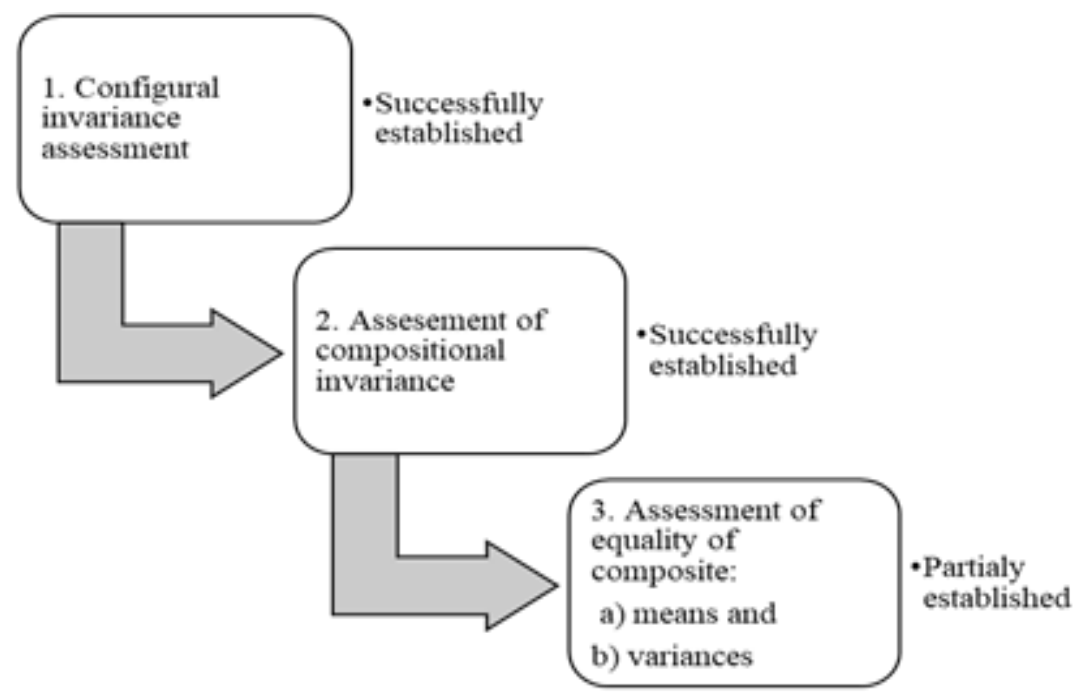

Figure 4. Three steps to test the measurement invariance of composite models (MICOM).

After running the permutation with 5000 subsamples, and 300 iterations in two tail testing $5 \%$ level of significance, the results indicated that the MICOM was successfully established for step one. Additionally, step two was established, because the original correlations were larger than $5 \%$ and $p$ values $>0.05$ ). Next, in step three part a) the assessment of equality of composite mean only for service quality was not falling between $2.5 \%$ and $97.5 \%$ and the permutation p-value was less than $5 \%$, meaning there was a significant difference the between two groups (male and female) for this latent variable. In contrast, accessibility, safety and security were established, by comparing mean original difference (male-female), to be within the lower $(2.5 \%)$ and upper $(97.5 \%)$ boundaries. Furthermore, in part b) the variance of original differences for (male-female) fell between the $2.5 \%$ and $97.5 \%$ boundaries established. Consequently, in step three not all the composite equalities were established, and only partial measurement invariance was supported.

Finally, the results from the analysis and interpreting permutations revealed that only one of the relationships showed a statistically significant difference, i.e., between males and females, which is the relationship between safety and security with satisfaction ( $p$-value $<0.05)$.

To find the specific differences (heterogeneity) among groups (male vs. female), as well as age groups $(18-44$ vs. $\geq 45)$ the MGA using SmartPLS was considered for 
further analysis. Findings in Table 10 show that in the accessibility relationship with satisfaction (path coefficient/B $=-0.005$ for gender groups and $\mathrm{B}=-0.044$ for age groups, $p$-value $=0.978$ and $p$-value $=0.806$, respectively) there were no significant differences between males and females and different age groups. Similarly, results for the service quality and satisfaction (path coefficient $/ \mathrm{B}=-0.347$ and $\mathrm{B}=0.234, p$-value $=0.174$ and $p$-value $=0.349$ for gender and age groups, respectively) display non-significance among them to predict PV user satisfaction about PT service. In contrast, in the case of the safety and security relationship with satisfaction, there was a significant difference between both gender and age groups (path coefficient $/ \mathrm{B}=0.610$ and $\mathrm{B}=-0.500, p$-value $=0.014$ and $p$-value $=0.027$, respectively) as the $p$-value is less than 0.05 level of confidence.

Table 10. Partial least square multi-group analysis (PLS-MGA) results: Male vs. Female.

\begin{tabular}{lllll}
\hline \multicolumn{2}{c}{ Gender (Male vs. Female) } & \multicolumn{2}{c}{ Age (18-44 vs. $\geq$ 45) } \\
\hline Relationship & B-Value & $p$-Value & B-Value & $p$-Value \\
\hline $\begin{array}{c}\text { Accessibility -> } \\
\text { Satisfaction }\end{array}$ & -0.005 & $0.978 \mathrm{ns.}$ & -0.044 & $0.806 \mathrm{ns.}$ \\
\hline $\begin{array}{c}\text { Service quality-> } \\
\text { Satisfaction }\end{array}$ & -0.347 & $0.174 \mathrm{~ns}$. & 0.234 & $0.349 \mathrm{ns.}$ \\
\hline $\begin{array}{l}\text { Safety and } \\
\text { security-> } \\
\text { Satisfaction }\end{array}$ & 0.610 & $0.014^{* * *} \mathrm{sg}$. & -0.500 & $0.027^{* * *} \mathrm{sg}$. \\
*** Significance value at 5\% level of confidence. & & &
\end{tabular}

\section{Discussion}

\subsection{Theoretical Implications}

To develop a sustainable transport mode, it is important to increase the number of participants in public transportation and limit private vehicle usage. This can be achieved by improving the satisfaction level of public transportation and PV users. This paper has improved the body of knowledge in this field by proposing a theoretical model including three main relationships, to predict the satisfaction of PV users. This is the first study to investigate the perspective of PV users about PT service quality during COVID-19 using a PLS-SEM approach.

The results of this study identified the main factor that contributes to satisfaction of PV users which was perceived service quality, this is supported by several previous studies, for example, the cost of public transport is strongly associated with satisfaction $[23,57,90,91]$. Moreover, followed accessibility perception was also found as a significant factor to contribute to satisfaction which is in line with Lättman et al. [53]. On study pointed out that the overall satisfaction is related to easy transferring [92]. However, among other variables, predictable safety and security were not significant factors in contributing to the PV users' satisfaction, because the data was collected during COVID-19 in October and November 2020, when people paid more attention to safety issues than in previous safety assessments [93]. These findings are also compatible with some recent studies during COVID-19 on whether public transport users perceived increased safety, and whether users were highly satisfied with public transportation [94]. Another study stated that some people sometimes feel unsafe with public transportation [95].

In contrast, some other previous researchers have argued that the perception of safety and security has been recognized as the main factor significantly related to satisfaction of PT users $[25,91,96]$. Safety as a crucial factor for satisfaction has been explored in previous research [97]. Moreover, findings from PLS-MGA show that in the analysis of the sociodemographic characteristics (gender and age), there was a significant difference among both groups in the formulation of satisfaction associated with safety and security, which is in line with a recent study [98]. This is because each gender and age group has its own perception of service quality. 


\subsection{Managerial Implications}

In terms of practical implications, the results of this study have proposed several critical implications for PT service providers in the development of passenger transportation, which will, result in retaining the current PT ridership and attracting more PV users. It is important for PT local authorities and policy-makers to be accurately focused on how PT users perceive their quality of service. This may help PT operators to prioritize strategies to retain and attract PT users and minimize attention paid to less relevant variables. For example, according to the results, policymakers and practitioners may first consider the service quality attributes, including frequency, service hours, punctuality, speed, cost and provided information to increase the satisfaction of PV users, followed by accessibility, including access to/from stations, transfer to different transport modes and availability of space for individuals inside the vehicle, as they are the most significant variables informing of satisfaction.

However, substantial improvement is needed for safety and security variables to attract PV users, who were not satisfied with the provided service. For instance, PT operators should provide sufficient service in PT and stations, and offer better temperature control inside the vehicle, especially during the pandemic. Moreover, service providers should not ignore improvement to lighting and installation of more CCTV cameras in PT and around the station area to reduce crime. Another critical factor in insuring improvement of passenger satisfaction is increasing the cleanliness of the vehicle and stations. Providing more ventilation and sanitation inside PT vehicles and at stations, would lead to an improved to an improved PT system better equipped for increasing PT users.

\section{Conclusions and Future Research Direction}

In summary, this paper investigated several key factors, namely perceived service quality, accessibility, safety and security that estimate that influence the overall satisfaction level of PV usage in Budapest, Hungary. This is the first research investigating this relationship using PV users' perception data from an Eastern European country and during COVID-19 by applying the PLS-SEM approach. The paper highlighted, that some satisfaction issues became more significant, while the importance of others was mitigated due to the unusual circumstances.

The results of this study contribute to enhance knowledge of both theoretical and practical implications. Concerning the theoretical part, this paper expands the essential knowledge in this field. In addition, the proposed model provides a better understanding of the relationship between different perceived constructs and satisfaction. As a further novelty, PLS-MGA was implemented to test the difference in perception among age and gender groups on the formation of PV user satisfaction.

In terms of the practical implications, the findings in the presented research are helpful for both public transport operators and decision-makers aiming to enhance their efficiency plan to attract PV users toward more sustainable transportation. The results indicate which manifest (observed) variables have a high weight on the latent (unobserved) variable. Based on these results, the authorities and decision-makers can focus on those variables more likely to improve the satisfaction of PV passengers.

Undoubtedly, it has been observed that the aim of this study was successfully fulfilled, contributing several benefits for theoretical and practical implications. Nevertheless, this research is not without limitations, which may provide research direction for future studies, and need to be acknowledged. From a transport planning perspective, first, in this study the sample size is comparatively small compared with the target of Budapest citizens and public transportation firms. Therefore, future studies should expand the sample size and involve more participants to enhance the results and make better decisions. Second, the data was collected during COVID-19 in Budapest in October and November 2020. Further study could address a longitudinal survey to find the main factors influencing PV users satisfaction and make a comparative analysis. Third, the effect of gender and age groups in this paper have been examined in the formulation of satisfaction of PV users. Thus, future 
research is recommended to understand the impact of other individuals' socio-economic characteristics, for example, a comparison among education level, and income groups.

On the other hand, from the methodology point of view, it is also worth mentioning that combining both observed heterogeneity (PLS-MGA) and unobserved heterogeneity (FIMIX, PLS), or use of necessary condition analysis (NCA) with large data might give more robust results. A possible further study may also consider the combination between discrete choice models for example; the ordered logit model and PLS-MGA to conduct a more in-depth heterogeneity analysis. Moreover, a hybrid approach is suggested between Structural Equation Models (SEMs) and Multi-Criteria Decision Making (MCDM) techniques, to find comparisons and differences [99]. However, the survey procedures for both SEM and MCDM techniques are quite different. Recently, several researchers recommended employing an integrated approach between Bayesian Network (BN) with SEM, and BN with PLS-SEM as a powerful tool that can be utilized to enhance new theories or frameworks in any field of knowledge $[18,100]$. Especially, a combination of BN and PLS-SEM for determining the interrelationship between service quality factors and dealing with the heterogeneity analysis is recommended [30,34].

Author Contributions: Conceptualization, K.I.; methodology, K.I.; Validation, K.I.; formal analysis, K.I.; investigation, S.D. and K.I.; resources, K.I.; data curation, K.I.; writing-original draft preparation, K.I.; writing — review and editing, S.D. and KI; visualization, S.D. Supervision, S.D. All authors have read and agreed to the published version of the manuscript.

Funding: S. Duleba acknowledges the support of the János Bolyai Research Fellowship of the Hungarian Academy of Sciences (No.BO/8/20).

Institutional Review Board Statement: Not applicable.

Informed Consent Statement: Not applicable.

Data Availability Statement: Not applicable.

Conflicts of Interest: The authors declare no conflict of interest. The funders had no role in the design of the study; in the collection, analysis, or interpretation of data; in the writing of the manuscript, or in the decision to publish the results. 


\section{Appendix A}
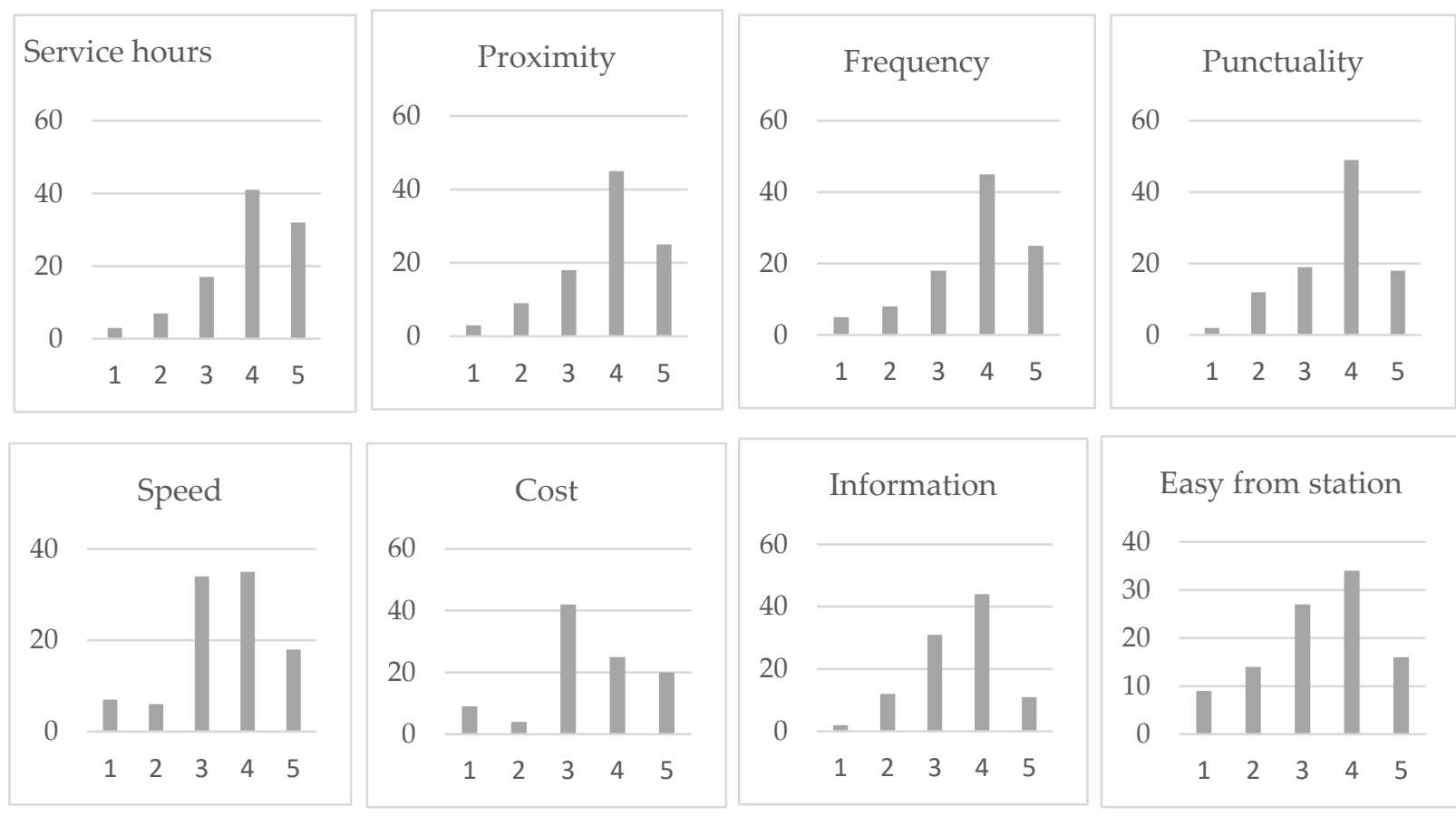

\section{Easy from station}
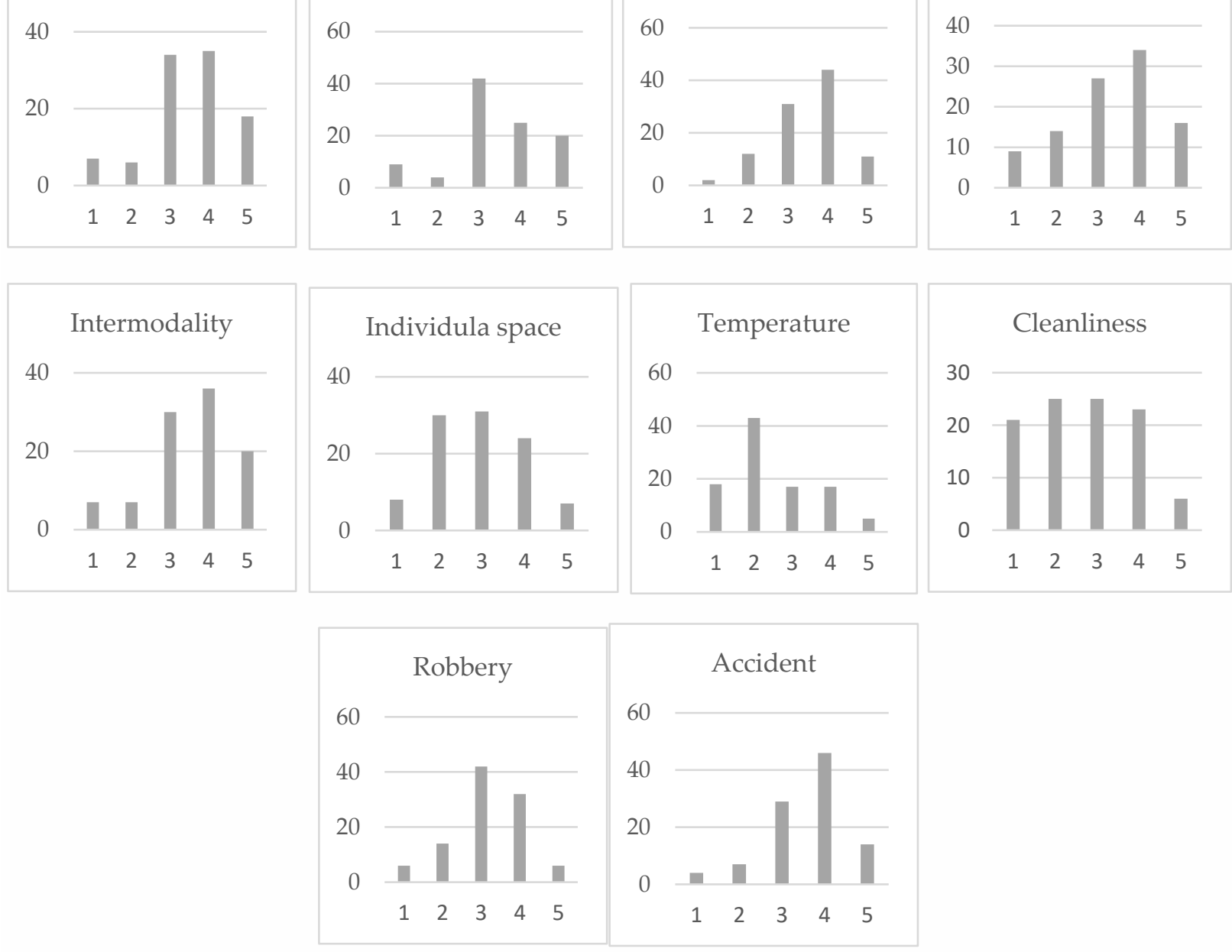

Figure A1. Score distribution for each variable.

\section{References}

1. Banister, D. The sustainable mobility paradigm. Transp. Policy 2008, 15, 73-80. [CrossRef]

2. de Oña, J. Understanding the mediator role of satisfaction in public transport: A cross-country analysis. Transp. Policy 2020, 100, 129-149. [CrossRef]

3. Holmgren, J. An analysis of the determinants of local public transport demand focusing the effects of income changes. Eur. Transp. Res. Rev. 2013, 5, 101-107. [CrossRef]

4. Allen, J.; Eboli, L.; Forciniti, C.; Mazzulla, G.; Ortúzar, J.D.D. The role of critical incidents and involvement in transit satisfaction and loyalty. Transp. Policy 2019, 75, 57-69. [CrossRef] 
5. De Oña, J.; de Oña, R.; Eboli, L.; Forciniti, C.; Mazzulla, G. An ordered regression model to predict transit passengers' behavioural intentions. Case Stud. Transp. Policy 2018, 6, 449-455. [CrossRef]

6. Mandhani, J.; Nayak, J.K.; Parida, M. Interrelationships among service quality factors of Metro Rail Transit System: An integrated Bayesian networks and PLS-SEM approach. Transp. Res. Part A: Policy Pract. 2020, 140, 320-336. [CrossRef]

7. Lättman, K.; Friman, M.; Olsson, L.E. Restricted car-use and perceived accessibility. Transp. Res. Part D Transp. Environ. 2020, 78, 102213. [CrossRef]

8. De Oña, J.; Estévez, E.; De Oña, R. Perception of Public Transport Quality of Service among Regular Private Vehicle Users in Madrid, Spain. Transp. Res. Rec. J. Transp. Res. Board 2020, 2674, 213-224. [CrossRef]

9. De Oña, J.; Estévez, E.; de Oña, R. Public transport users versus private vehicle users: Differences about quality of service, satisfaction and attitudes toward public transport in Madrid (Spain). Travel Behav. Soc. 2020, 23, 76-85. [CrossRef]

10. Beirão, G.; Cabral, J.A.S. Understanding attitudes towards public transport and private car: A qualitative study. Transp. Policy 2007, 14, 478-489. [CrossRef]

11. Miralles-Guasch, C.; Melo, M.M.; Sarda, O.M. On user perception of private transport in Barcelona Metropolitan area: An experience in an academic suburban space. J. Transp. Geogr. 2014, 36, 24-31. [CrossRef]

12. Jenelius, E.; Cebecauer, M. Impacts of COVID-19 on public transport ridership in Sweden: Analysis of ticket validations, sales and passenger counts. Transp. Res. Interdiscip. Perspect. 2020, 8, 100242. [CrossRef]

13. Bucsky, P. Modal share changes due to COVID-19: The case of Budapest. Transp. Res. Interdiscip. Perspect. $2020,8,100141$. [CrossRef]

14. De Oña, J.; de Oña, R. Quality of Service in Public Transport Based on Customer Satisfaction Surveys: A Review and Assessment of Methodological Approaches. Transp. Sci. 2015, 49, 605-622. [CrossRef]

15. Echaniz, E.; Dell'Olio, L.; Ibeas, A. Modelling perceived quality for urban public transport systems using weighted variables and random parameters. Transp. Policy 2018, 67, 31-39. [CrossRef]

16. Zefreh, M.M.; Hussain, B.; Sipos, T. In-Depth Analysis and Model Development of Passenger Satisfaction with Public Transportation. KSCE J. Civ. Eng. 2020, 24, 3064-3073. [CrossRef]

17. De Oña, J.; Estévez, E.; de Oña, R. How does private vehicle users perceive the public transport service quality in large metropolitan areas? A European comparison. Transp. Policy 2021, 112, 173-188. [CrossRef]

18. Díez-Mesa, F.; de Oña, R.; de Oña, J. Bayesian networks and structural equation modelling to develop service quality models: Metro of Seville case study. Transp. Res. Part A: Policy Pract. 2018, 118, 1-13. [CrossRef]

19. Fu, X.; Juan, Z. Exploring the psychosocial factors associated with public transportation usage and examining the "gendered" difference. Transp. Res. Part A: Policy Pract. 2017, 103, 70-82. [CrossRef]

20. Yaya, L.H.P.; Fortià, M.F.; Canals, C.S.; Marimon, F. Service quality assessment of public transport and the implication role of demographic characteristics. Public Transp. 2014, 7, 409-428. [CrossRef]

21. Simićević, J.; Milosavljević, N.; Djoric, V. Gender differences in travel behaviour and willingness to adopt sustainable behaviour. Transp. Plan. Technol. 2016, 39, 527-537. [CrossRef]

22. Jomnonkwao, S.; Champahom, T.; Ratanavaraha, V. Methodologies for Determining the Service Quality of the Intercity Rail Service Based on Users' Perceptions and Expectations in Thailand. Sustainability 2020, 12, 4259. [CrossRef]

23. De Oña, J.; de Oña, R.; Eboli, L.; Mazzulla, G. Perceived service quality in bus transit service: A structural equation approach Transp. Policy 2013, 29, 219-226. [CrossRef]

24. Babin, B.J.; Hair, J.F.; Boles, J.S. Publishing Research in Marketing Journals Using Structural Equation Modeling. J. Mark. Theory Pract. 2008, 16, 279-286. [CrossRef]

25. Ha, S.T.; Ibrahim, W.H.W.; Lo, M.C.; Mah, Y.S. Factors Affecting Satisfaction and Loyalty in Public Transport using Partial Least Squares Structural Equation Modeling (PLS-SEM). Transport 2019, 10, 60.

26. Farooq, M.S.; Salam, M.; Fayolle, A.; Jaafar, N.; Ayupp, K. Impact of service quality on customer satisfaction in Malaysia airlines: A PLS-SEM approach. J. Air Transp. Manag. 2018, 67, 169-180. [CrossRef]

27. Nguyen-Phuoc, D.Q.; Tran, A.T.P.; Van Nguyen, T.; Le, P.T.; Su, D.N. Investigating the complexity of perceived service quality and perceived safety and security in building loyalty among bus passengers in Vietnam-A PLS-SEM approach. Transp. Policy 2020, 101, 162-173. [CrossRef]

28. Bordagaray, M.; Dell'Olio, L.; Ibeas, A.; Cecín, P. Modelling user perception of bus transit quality considering user and service heterogeneity. Transp. A: Transp. Sci. 2013, 10, 705-721. [CrossRef]

29. Duleba, S.; Moslem, S. Sustainable Urban Transport Development with Stakeholder Participation, an AHP-Kendall Model: A Case Study for Mersin. Sustainability 2018, 10, 3647. [CrossRef]

30. Mandhani, J.; Nayak, J.K.; Parida, M. Establishing service quality interrelations for Metro rail transit: Does gender really matter? . Transp. Res. Part D: Transp. Environ. 2021, 97, 102888. [CrossRef]

31. Sarstedt, M.; Ringle, C.M.; Cheah, J.-H.; Ting, H.; Moisescu, O.I.; Radomir, L. Structural model robustness checks in PLS-SEM. Tour. Econ. 2019, 26, 531-554. [CrossRef]

32. Campus, K.; Communication, P. Using Potential accessibility measure for urban public transportation planning: A case study of denizli, Turkey. Promet-Traffic Transp. 2014, 26, 129-137.

33. Friman, M.; Fellesson, M. Service Supply and Customer Satisfaction in Public Transportation: The Quality Paradox. J. Public Transp. 2009, 12, 57-69. [CrossRef] 
34. Ibrahim, A.; Borhan, M.; Yusoff, N.M.; Ismail, A.; Yazid, M.M.; Yunin, N.M.; Sotaro, Y. Gender and Age Do Matter: Exploring the Effect of Passengers' Gender and Age on the Perception of Light Rail Transit Service Quality in Kuala Lumpur, Malaysia. Sustainability 2021, 13, 990. [CrossRef]

35. Tavares, V.B.; Lucchesi, S.T.; Larranaga, A.M.; Cybis, H.B.B. Influence of public transport quality attributes on user satisfaction of different age cohorts. Case Stud. Transp. Policy 2021, 9, 1042-1050. [CrossRef]

36. Cheah, J.-H.; Thurasamy, R.; Memon, M.A.; Chuah, F.; Ting, H. Multigroup Analysis using SmartPLS: Step-by-Step Guidelines for Business Research. Asian J. Bus. Res. 2020, 10. [CrossRef]

37. Zeng, N.; Liu, Y.; Gong, P.; Hertogh, M.; König, M. Do right PLS and do PLS right: A critical review of the application of PLS-SEM in construction management research. Front. Eng. Manag. 2021, 8, 356-369. [CrossRef]

38. Yuan, Y.; Yang, M.; Feng, T.; Rasouli, S.; Li, D.; Ruan, X. Heterogeneity in passenger satisfaction with air-rail integration services: Results of a finite mixture partial least squares model. Transp. Res. Part A Policy Pract. 2021, 147, 133-158. [CrossRef]

39. Bayonne, E.; Marin-Garcia, J.A.; Alfalla-Luque, R. Partial least squares (PLS) in Operations Management research: Insights from a systematic literature review. J. Ind. Eng. Manag. 2020, 13, 565-597. [CrossRef]

40. Memon, M.A.; Ting, H.; Ramayah, T.; Chuah, F.; Cheah, J. A review of the methodological misconceptions and guidelines related to the application of structural equation modeling. J. Appl. Struct. Equ. Modeling 2017, 1, i-xiii. [CrossRef]

41. Ringle, C.M.; Sarstedt, M.; Mitchell, R.; Gudergan, S.P. Partial least squares structural equation modeling in HRM research. Int. J. Hum. Resour. Manag. 2018, 31, 1617-1643. [CrossRef]

42. Ghasemy, M.; Teeroovengadum, V.; Becker, J.-M.; Ringle, C.M. This fast car can move faster: A review of PLS-SEM application in higher education research. High. Educ. 2020, 80, 1121-1152. [CrossRef]

43. Hair, F., Jr.; Matthews, L.M.; Matthews, R.L.; Magdeburg, O. PLS-SEM or CB-SEM: Updated guidelines on which method to use Marko Sarstedt. Int. J. Multivar. Data Anal. 2017, 1, 107-123. [CrossRef]

44. Askari, S.; Peiravian, F.; Tilahun, N.; Baseri, M.Y. Determinants of users' perceived taxi service quality in the context of a developing country. Transp. Lett. 2020, 13, 125-137. [CrossRef]

45. Allen, J.; Bellizzi, M.G.; Eboli, L.; Forciniti, C.; Mazzulla, G. Service quality in a mid-sized air terminal: A SEM-MIMIC ordinal probit accounting for travel, sociodemographic, and user-type heterogeneity. J. Air Transp. Manag. 2020, 84, 101780. [CrossRef]

46. Groß, M. Heterogeneity in consumers' mobile shopping acceptance: A finite mixture partial least squares modelling approach for exploring and characterising different shopper segments. J. Retail. Consum. Serv. 2018, 40, 8-18. [CrossRef]

47. McDougall, G.H.; Levesque, T. Customer satisfaction with services: Putting perceived value into the equation. J. Serv. Mark. 2000, 14, 392-410. [CrossRef]

48. Naveen, B.R.; Gurtoo, A. The Cause Effect Relationship Model of Service Quality in relation with Overall Satisfaction. Transp. Res. Procedia 2020, 48, 1694-1721. [CrossRef]

49. Sam, E.F.; Hamidu, O.; Daniels, S. SERVQUAL analysis of public bus transport services in Kumasi metropolis, Ghana: Core user perspectives. Case Stud. Transp. Policy 2017, 6, 25-31. [CrossRef]

50. Deb, S.; Ahmed, M.A. Determining the service quality of the city bus service based on users' perceptions and expectations. Travel Behav. Soc. 2018, 12, 1-10. [CrossRef]

51. Sarkar, P.P.; Mallikarjuna, C. Effect of perception and attitudinal variables on mode choice behavior: A case study of Indian city, Agartala. Travel Behav. Soc. 2018, 12, 108-114. [CrossRef]

52. Friman, M.; Lättman, K.; Olsson, L.E. Public Transport Quality, Safety, and Perceived Accessibility. Sustainability 2020, $12,3563$. [CrossRef]

53. Lättman, K.; Friman, M.; Olsson, L.E. Perceived Accessibility of Public Transport as a Potential Indicator of Social Inclusion. Soc. Incl. 2016, 4, 36-45. [CrossRef]

54. Dell'Olio, L.; Ibeas, A.; Cecín, P. Modelling user perception of bus transit quality. Transp. Policy 2010, 17, 388-397. [CrossRef]

55. Tiglao, N.C.C.; De Veyra, J.M.; Tolentino, N.J.Y.; Tacderas, M.A.Y. Research in Transportation Economics the perception of service quality among paratransit users in Metro Manila using structural equations modelling (SEM) approach. Res. Transp. Econ. 2020, 83. [CrossRef]

56. Eboli, L.; Mazzulla, G. A methodology for evaluating transit service quality based on subjective and objective measures from the passenger's point of view. Transp. Policy 2011, 18, 172-181. [CrossRef]

57. Grujičić, D.; Ivanovic, I.; Jovic, J.; Djoric, V. Customer perception of service quality in public transport. Transport 2014, 29, 285-295. [CrossRef]

58. Lai, W.-T.; Chen, C.-F. Behavioral intentions of public transit passengers-The roles of service quality, perceived value, satisfaction and involvement. Transp. Policy 2011, 18, 318-325. [CrossRef]

59. Lunke, E.B. Commuters' satisfaction with public transport. J. Transp. Health 2020, 16, 100842. [CrossRef]

60. Tyrinopoulos, Y.; Antoniou, C. Public transit user satisfaction: Variability and policy implications. Transp. Policy 2008, 15, 260-272. [CrossRef]

61. Daniels, R.; Mulley, C. Explaining walking distance to public transport: The dominance of public transport supply. J. Transp. Land Use 2013, 6, 5-20. [CrossRef]

62. Hu, L.; Cao, J.; Yang, J. Planning for accessibility. Transp. Res. Part D Transp. Environ. 2020, 88, 102575. [CrossRef]

63. Cavallaro, F.; Dianin, A. An innovative model to estimate the accessibility of a destination by public transport. Transp. Res. Part D Transp. Environ. 2020, 80, 102256. [CrossRef] 
64. Su, D.N.; Nguyen-Phuoc, D.Q.; Johnson, L.W. Effects of perceived safety, involvement and perceived service quality on loyalty intention among ride-sourcing passengers. Transportation 2019, 48, 369-393. [CrossRef]

65. Laura Laura Eboli, University of Calabria; Gabriella Gabriella Mazzulla, University of Calabria Service Quality Attributes Affecting Customer Satisfaction for Bus Transit. J. Public Transp. 2007, 10, 21-34. [CrossRef]

66. Coppola, P.; Silvestri, F. Assessing travelers' safety and security perception in railway stations. Case Stud. Transp. Policy 2020, 8 , 1127-1136. [CrossRef]

67. Irfan, S.M.; Kee, D.M.H.; Shahbaz, S. Service quality and rail transport in Pakistan: A passenger perspective. World Appl. Sci. J. 2012, 18, 361-369. [CrossRef]

68. Rossetti, T.; Guevara, C.A.; Galilea, P.; Hurtubia, R. Modeling safety as a perceptual latent variable to assess cycling infrastructure. Transp. Res. Part A Policy Pract. 2018, 111, 252-265. [CrossRef]

69. Hair, J.F.; Sarstedt, M.; Ringle, C.M.; Mena, J.A. An assessment of the use of partial least squares structural equation modeling in marketing research. J. Acad. Mark. Sci. 2012, 40, 414-433. [CrossRef]

70. Concern, C. People's Perceptions of Personal Security and Their Concerns about Crime on Public Transport: Research Findings; Department for Transport: Greater London, UK, 2004.

71. Şimşekoğlu, Ö.; Nordfjærn, T.; Rundmo, T. The role of attitudes, transport priorities, and car use habit for travel mode use and intentions to use public transportation in an urban Norwegian public. Transp. Policy 2015, 42, 113-120. [CrossRef]

72. Tenenhaus, M.; Vinzi, V.E.; Chatelin, Y.M.; Lauro, C. PLS path modeling. Comput. Stat. Data Anal. 2005, 48, 159-205. [CrossRef]

73. Mateos-Aparicio, G. Partial Least Squares (PLS) Methods: Origins, Evolution, and Application to Social Sciences. Commun. Stat. Theory Methods 2011, 40, 2305-2317. [CrossRef]

74. Ali, M.; Ramayah, T.; Cheah, J. PLS-SEM STATISTICAL PROGRAMS: A REVIEW. J. Appl. Struct. Equ. Model. 2021, 5. [CrossRef]

75. hao, Z.; Feng, Y.; Hu, Q. Impact of top management leadership styles on ERP assimilation and the role of organizational learning. Inf. Manag. 2017, 54, 1-257.

76. Memon, M.A.; Ting, H.; Cheah, J.-H.; Thurasamy, R.; Chuah, F.; Cham, T.H. Sample Size for Survey Research: Review and Recommendations. J. Appl. Struct. Equ. Model. 2020, 4. [CrossRef]

77. Sarstedt, M.; Henseler, J.; Ringle, C.M. Multigroup Analysis in Partial Least Squares (PLS) Path Modeling: Alternative Methods and Empirical Results. New Chall. Int. Mark. 2011, 22, 195-218. [CrossRef]

78. Hungarian Central Statistical Office. Available online: https://www.ksh.hu/search?q=Budapest (accessed on 10 July 2021).

79. Budapest Public Transportation information. Available online: https://bkk.hu/apps/docs/turisztikai_kiadvany_en.pdf (accessed on 10 September 2021).

80. Kock, N. Common method bias in PLS-SEM: A full collinearity assessment approach. Int. J. e-Collab. (Ijec) 2015, 11, 1-10. [CrossRef]

81. Henseler, J.; Ringle, C.M.; Sinkovics, R.R. The Use of Partial Least Squares Path Modeling in International Marketing. In Advances in International Marketing; Sinkovics, R.R., Ghauri, P.N., Eds.; Emerald Group Publishing Limited: Bradford, UK, 2009 ; pp. 277-319. [CrossRef]

82. Hair, J.F.; Risher, J.J.; Sarstedt, M.; Ringle, C.M. When to use and how to report the results of PLS-SEM. Eur. Bus. Rev. 2019, 31, 2-24. [CrossRef]

83. Hair, J.F., Jr.; Sarstedt, M.; Hopkins, L.; Kuppelwieser, V.G. Partial least squares structural equation modeling (PLS-SEM). Eur. Bus. Rev. 2014, 26, 106-121. [CrossRef]

84. Sarstedt, M.; Ringle, C.M.; Smith, D.; Reams, R.; Hair, J.F. Partial least squares structural equation modeling (PLS-SEM): A useful tool for family business researchers. J. Fam. Bus. Strat. 2014, 5, 105-115. [CrossRef]

85. Henseler, J.; Ringle, C.M.; Sarstedt, M. Testing measurement invariance of composites using partial least squares. Int. Mark. Rev. 2016, 33, 405-431. [CrossRef]

86. Hair, J.F.; Hult, G.T.M.; Ringle, C.M.; Sarstedt, M.; Danks, N.P.; Ray, S. Partial Least Squares Structural Equation Modeling (PLS-SEM) Using R. 2021. Secur. Anal. Portf. Manag. 2021. [CrossRef]

87. Hair, J.F., Jr.; Hult, G.T.M.; Ringle, C.M.; Sarstedt, M. A Primer on Partial Least Squares Structural Equation Modeling (PLS-SEM); Sage Publications: New York, NY, USA, 2021.

88. Henseler, J.; Hubona, G.; Ray, P.A. Using PLS path modeling in new technology research: Updated guidelines. Ind. Manag. Data Syst. 2016, 116, 2-20. [CrossRef]

89. Wetzels, M.; Odekerken-Schröder, G.; Van Oppen, C. Using PLS path modeling for assessing hierarchical construct models: Guidelines and empirical illustration. MIS Q. 2009, 33, 177-195. [CrossRef]

90. Van Lierop, D.; Badami, M.G.; El-Geneidy, A.M. What influences satisfaction and loyalty in public transport? A review of the literature. Transp. Rev. 2017, 38, 52-72. [CrossRef]

91. Mouwen, A. Drivers of customer satisfaction with public transport services. Transp. Res. Part A Policy Pract. 2015, 78, 1-20. [CrossRef]

92. Susilo, Y.O.; Cats, O. Exploring key determinants of travel satisfaction for multi-modal trips by different traveler groups. Transp. Res. Part A Policy Pract. 2014, 67, 366-380. [CrossRef]

93. Wang, Y.; Wang, Y.; Chen, Y.; Qin, Q. Unique epidemiological and clinical features of the emerging 2019 novel coronavirus pneumonia (COVID-19) implicate special control measures. J. Med Virol. 2020, 92, 568-576. [CrossRef] 
94. Dong, H.; Ma, S.; Jia, N.; Tian, J. Understanding public transport satisfaction in post COVID-19 pandemic. Transp. Policy 2020, 101, 81-88. [CrossRef]

95. Cozens, P.; Neale, R.; Whitaker, J.; Hillier, D. Managing crime and the fear of crime at railway stations--a case study in South Wales (UK). Int. J. Transp. Manag. 2003, 1, 121-132. [CrossRef]

96. Nazrul, A.; Ibrahim, H.; Borhan, M.N.; Ismail, A. Rail-based public transport service quality and user satisfaction-A literature review. Promet-Traffic Transp. 2020, 32, 423-435, 2020.

97. Shiwakoti, N.; Stasinopoulos, P.; Vincec, P.; Qian, W.; Hafsar, R. Exploring how perceptive differences impact the current public transport usage and support for future public transport extension and usage: A case study of Melbourne's tramline extension. Transp. Policy 2019, 84, 12-23. [CrossRef]

98. Khaddar, S.; Fatmi, M.R. COVID-19: Are you satisfied with traveling during the pandemic? Transp. Res. Interdiscip. Perspect. 2020, 9, 100292. [CrossRef] [PubMed]

99. Moslem, S.; Alkharabsheh, A.; Ismael, K.; Duleba, S. An Integrated Decision Support Model for Evaluating Public Transport Quality. Appl. Sci. 2020, 10, 4158. [CrossRef]

100. Radzi, C.W.J.B.W.M.; Jenatabadi, H.S.; Hasbullah, M.B. Firm Sustainability Performance Index Modeling. Sustainability 2015, 7, 16196-16212. [CrossRef] 